\title{
System Efficiency Analysis of SOFC Coupling with Air, Mixed Air-Steam and Steam Gasification Fueled by Thailand Rice Husk
}

\author{
Pannipha Dokmaingam ${ }^{1, a,}$, Rajesh S. Kempegowda ${ }^{2, b}$, Suttichai Assabumrungrat ${ }^{3, c}$, \\ and Navadol Laosiripojana ${ }^{2, \mathrm{~d}}$ \\ 1 School of Health Science, Mae Fah Luang University, Chiang Rai 57100, Thailand \\ 2 The Joint Graduate School of Energy and Environment, King Mongkut's University of Technology \\ Thonburi, Bangkok 10140, Thailand \\ 3 Department of Chemical Engineering, Faculty of Engineering, Chulalongkorn University, Bangkok 10330, \\ Thailand \\ E-mail: adpannipha@gmail.com (Corresponding author), brajeshsk76@gmail.com, \\ csuttichai.a@chula.ac.th,dnavadol@kmutt.ac.th
}

\begin{abstract}
In this work, integrative biomass gasification with solid oxide fuel cell (SOFC) system using rice husk as feedstock was studied under various operations. It was found that the stand-alone mixed air-steam gasification provided significant higher benefit than alone air and steam gasification. The mathematical model was developed to predict the electrical, thermal and overall efficiency of the system. It was found that the SOFC with steam gasification also provided the greatest overall efficiency of $96 \%$. Hence, the steam gasification is a promising option for coupling with SOFC to generate electricity from biomass.
\end{abstract}

Keywords: Gasification, SOFC, combined heat and power, simulation, biomass.

ENGINEERING JOURNAL Volume 21 Issue 4

Received 18 November 2016

Accepted 5 February 2017

Published 31 July 2017

Online at http://www.engj.org/

DOI:10.4186/ej.2017.21.4.95 


\section{Introduction}

Fuel cells have been known as one of the power generation technology by using electrochemical reaction. This is different from conventional power generation technology, i.e. gas turbine or steam turbine, which electricity is produced via mechanical process. Theoretically, a single unit fuel cell is usually consisted of three basic sections, i.e. anode, cathode and electrolyte. The gaseous electrochemical reactants are diffused though the electrodes and then converted to electricity at electrodes/electrolyte interfaces. One of premising fuel cell is Solid Oxide Fuel Cell (SOFC). It is more preferred than other fuel cells since it able to handle a wide range of hydrocarbon fuels [1]. SOFC is fabricated from solid materials and operated at high temperatures $\left(700-1000^{\circ} \mathrm{C}\right)$. SOFC could be designed as either tubular or planar configuration $[2,3]$. During operating, hydrocarbons could be internally or externally reformed (depending on the composition of the hydrocarbon fuels and the configuration of solid cell) to $\mathrm{H}_{2}$ and $\mathrm{CO}$ as the main reactants for SOFC. And then electricity is also generated together with $\mathrm{H}_{2} \mathrm{O}$ and $\mathrm{CO}_{2}$ [4]. Since $\mathrm{H}_{2}$ and $\mathrm{CO}$ is benefited for SOFC, the efficiency of SOFC, which is fuelled by methane, is higher than a hydrogen-fuelled system [5]. Essentially, the released heat from exothermic electrochemical reactions can be powerfully applied for cogeneration and/or bottoming cycle. This is benefited for stationary power generation applications. This results in several integrated SOFC system. Now a day, there are several promising SOFC cogeneration systems. For example, SOFC-Gas Turbine system (SOFC-GT), SOFC-Combined Heat and Power system (SOFC-CHP), SOFC-Micro gas turbine (SOFC-MGT) hybrid system, SOFC integrated distillation column (SOFC-DIS) [6-11]. For the SOFC-GT application, Palsson et al. [6] investigated a 500kW methane-fuelled SOFC-GT system. Their system consisted of preheaters, a pre-reformer, a SOFC stack, a combustor, an air compressor, a booster and an expander. After that, this SOFC-GT system was integrated with a $\mathrm{CO}_{2}$ capture in the work of Fredriksson [8]. They reported that electrical efficiency of this system is higher than $60 \%$. Meanwhile, the combination of a SOFC stack, a desulfurizer, a power conversion and system controllers was studied by Fontell et al. [12]. Their results revealed that the system efficiency achieved is around $85 \%$. If the desulfurizer unit was removed and replaced with a power conversion and controllers, the maximum system efficiency could be reduced to $52 \%$ [13]. In the case of SOFC-MGT, it is flexible for several type of fuel and provides the high energy conversion $[9,14]$. The combination of biomass gasification with SOFC and/or micro gas turbine (MGT) for small-scale CHP was also simulated. Sucipta et al. [9] developed mathematical model of internal reforming SOFC integrated with MGT and fueled by differenced composition of gasified biomass fuel. It was found that the system biomass is still low when air was used as gasified agent. The pressurized SOFC-MGT configuration showed the maximum efficiency of $36 \%$, whereas that from SOFC-MGT was estimated at $23 \%$. Until now, the thermodynamic analysis of SOFC integrated with biomass gasification system (with various gasification agents) has been limited [14]. Alternatively, the performance of SOFC-DIS system was also investigated. The interested system consists of a distillation column, a EtOH/H2O heater, a air heater, a anode preheater, a reformer, a SOFC stack and an afterburner [11]. The simulation results showed the overall electrical efficiency is around $33.3 \%$. Conventionally, biomass gasification is integrated with engines and/or gas turbines to generate electricity. However, electrical efficiency of these integrated systems is only $20-30 \%$ of the lower heating value (LHV) of biomass feedstock. To enhance the efficiency of biomass utilization, the coupling of biomass gasifier with SOFC is one of interested option. Recently, Omosun et al. [15] studied SOFC fuelled by the product gas from gasified biomass. The overall efficiency of their system is $59.6 \%$. Then novel autothermal type gasifier coupling with SOFC was considered by Panopoulos et al. [14]. The hot exhaust in the combustor is directly utilized in the autothermal gasifier. They reported that the electrical efficiency is $36 \%$ and the thermal efficiency is $14 \%$ when hydrogen utilization factor (Uf) is 0.7 and current density is $2500 \mathrm{~A} / \mathrm{m}^{2}$.

From the previous study, SOFC had been integrated with several technology. However, the efficiency of the integrated systems is recommend to improve when compared the conventionally biomass power generation technology. So the alternative integrated system would be present in this study. The set of mathematical modeling was developed in order to predict the behavior of biomass gasification integrated with SOFC system in terms of thermal efficiency, electrical efficiency and overall efficiency. The composition of lignocellulosic biomass, in the present work, is based on local rice husk since it is the major crop residue of Thailand. The effects of operating conditions (i.e. inlet oxidant/fuel ratio, steam/air ratio, and operating temperature) on the system efficiency were also determined. As electrical generation purpose, the optimum operating conditions of biomass gasification integrated with SOFC system were identified in 
this study. This is advantage for Thailand and agricultural countries where several types and numerous amount of lignocellulosic biomass are available.

\section{System Modeling}

AspenPlus ${ }^{\mathrm{TM}}$ (AP) is applied for system analysis in the present work since it was reported that the process simulation capabilities of AP enables to predict the reliable behavior of SOFC system $[16,17]$. This approach utilizes the existing capabilities of this process simulator and provides convenient way to perform detailed process study of SOFC based power generation cycles. The configuration of tubular SOFC in this model is developed based the design of Siemens-Westinghouse [18]. As shown in Fig. 1, a proposed process scheme consists of a fluidized bed gasifier, a hot gas cleaning, pre-heaters for fuel and air, SOFC stack and a burner. The details of the modeling approach were separated into gasifier, gas cleaning, SOFC and burner.

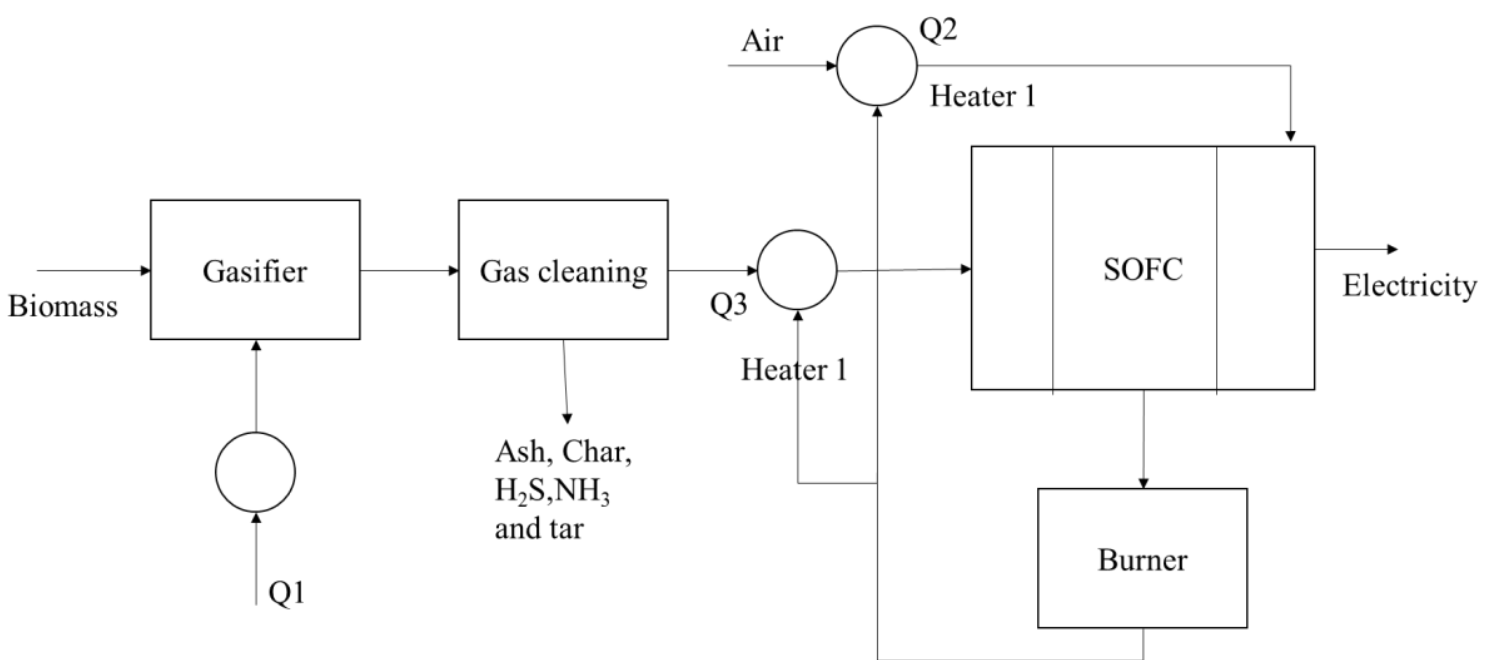

Fig. 1. Process schematic of the SOFC coupling with biomass gasification in the present work.

\subsection{Gasifier Modeling}

Gasifier is demonstrated by a DECOMP block of AP, where the decomposition of dry biomass with a known moisture content was introduced. Here, biomass is decomposed into elements such as $\mathrm{C}, \mathrm{H}, \mathrm{O}, \mathrm{N}$, $\mathrm{S}$, tar and ash. Rice husk was applied as biomass in the present work. The elemental composition of rice husk (i.e. carbon, hydrogen, oxygen and nitrogen) was analyzed by using ultimate analysis technique under dry-ash free basis. All analysis components are given in Table 1. In this research, tar was assumed as naphthalene compound [19] while ash was assumed as a non-conventional compound for the modeling purpose. The decomposed elements along with tar and ash were introduced in to the splitter to split the portion of carbon for recycle purpose. In this model, $10 \%$ of carbon portion was assumed to be nonreacted element in the Gibb's reactor. Furthermore, a ratio of $15 \%$ non-equilibrium char for circulating fluidized bed autothermal gasification was applied [20]. This allows methane concentration in the gasification subsection outlet is in the range of 5 to $10 \%(\mathrm{v} / \mathrm{v})$. This is agreed with commonly measured values. According to the literature about steam gasification experiments with catalytic in situ fluidized bed tar reduction, the amount of tar was specified to allow $1-5 \mathrm{~g} / \mathrm{m} 3$ in dry basis product gas [21]. The burner where combustion and gasification take place was modeled by a RGIBBS block in Aspen Plus ${ }^{\mathrm{TM}}$, in which the components considered are $\mathrm{CH}_{4}, \mathrm{CO}, \mathrm{CO} 2, \mathrm{H}_{2}, \mathrm{H}_{2} \mathrm{O}$, and $\mathrm{C}(\mathrm{s})$.

Table 1. Ultimate analysis of Rice Husk as received percentage by dry-ash free basis.

\begin{tabular}{lrrrr}
\hline & $\mathrm{C}$ & $\mathrm{H}$ & $\mathrm{N}$ & $\mathrm{O}$ \\
\hline \% by weight dry ash free basis & 48.7 & 6.96 & .36 & 43.98 \\
\hline
\end{tabular}




\subsection{SOFC Electrochemical Model}

This SOFC model was developed with objectives to analysis the thermodynamic and electricity parameters. In order to simplify the simulation, the assumptions for calculation in this work are listed below.

- The model is considered as steady state conditions.

- The active site is distributed uniformly over catalysis surface.

- The distribution of temperature and total pressure on the electrode are uniform.

- The conducting phases are considered as continuous and homogeneous.

- The gas concentration and the current density are uniform along with in the fuel channel.

- Only $\mathrm{H}_{2}$ gas is concerned as the electrochemical reactant because the rate of water-gas shift reaction is much faster than the rate of $\mathrm{CO}$ oxidization.

- Fuel utilization along the SOFC is fixed at 0.85. [15]

It is noted that these assumptions are acceptable since the length of the fuel channel is $3.8 \mathrm{~mm}$. which is relatively smalls $[10,16]$. As the basis of Zhang et al. [21], $\mathrm{H}_{2}$ was consumed via an electrochemical reaction. Meanwhile, air and syngas were heated up by liberated heat from the fuel cell. At the cathode, the inlet oxygen was separated from the air stream to provide oxygen-ions through the electrolyte. Nitrogen and unreacted oxygen in the air stream were sent out in the cathode exhaust stream. The main reactions taking place at the anode are:

Reforming and electrochemical reactions: At high temperature, $\mathrm{CH}_{4}$ is reformed on the anode surface to form $\mathrm{H}_{2}$ and $\mathrm{CO}$ (Eq. (1)), while the water-gas shift reaction also takes place to generate more $\mathrm{H}_{2}$ (Eq. (2)). The electrochemical reaction of the generated $\mathrm{H}_{2}$ with $\mathrm{O}_{2}$ - then occurs at the anode surface to release electrons for the external circuit (Eq. (3)). Based on these equations, the total hydrogen equivalent can be given from equation (Eq. (4)).

$$
\begin{gathered}
\mathrm{CH}_{4}+\mathrm{H}_{2} \mathrm{O} \leftrightarrow \mathrm{CO}+3 \mathrm{H}_{2} \\
\mathrm{CO}+\mathrm{H}_{2} \mathrm{O} \leftrightarrow \mathrm{CO}_{2}+\mathrm{H}_{2} \\
\mathrm{H}_{2}+1 / 2 \mathrm{O}_{2} \rightarrow \mathrm{H}_{2} \mathrm{O} \\
n_{\mathrm{H}_{2} \text {,equivalent }}=3 n \mathrm{CH}_{4}+n \mathrm{CO}
\end{gathered}
$$

It is noted that the required oxygen at the cathode can be calculated from the known hydrogen consumption using the following, Eq. (5):

$$
n_{\mathrm{O}_{2}, \text { required }}=\frac{1}{2} U_{f^{-} n_{\mathrm{H}_{2}} \text { equivalent }}
$$

Theoretically, $\mathrm{H}_{2}$ and $\mathrm{O}_{2}$ is directly influenced to electrical properties of the fuel cell, such as voltage and current density. The open circuit voltage of fuel cell, E, is calculated by using Nernst Equation (6).

$$
E=E^{o}+\frac{R T}{2 F} \ln \left(\frac{p_{\mathrm{H}_{2}} p_{\mathrm{O}_{2}}^{0.5}}{p_{\mathrm{H}_{2} \mathrm{O}}}\right)
$$

In the case of actual operation, the electrochemical reaction is irreversible. Therefore, the actual voltage is lower than the theoretical value of the open circuit voltage. This is the result of ohmic, activation and concentration losses.

Voltage loss calculations: Voltage loss calculations are calculated based on the ideal cell voltage as the potential redution by ohmic, activation, and concentration losses [22-24]. Theoretically, the ohmic loss is related to the limitation of electrical conductivity of fuel cell stack materials. The ohmic loss could be calculated by Eq. (9). It is noted that the ohmic resistance is the summation of all resistance at electrolyte, anode, cathode, and inters cell connector. It should be noted that ohmic resistance, $\boldsymbol{R}_{\text {ohm }}$, is calculated using material resistivity, length and cross sectional area of the electrodes and electrolyte. All material properties for calculating the internal cell resistance are listed in Table 2. 


$$
V_{o b m}=i \mathrm{R}_{o b m}
$$

For the tubular configuration, the tube dimensions and the current path flows were taken into account the circumferential current flows at the anode and cathode [24]. The current (i) and ohmic voltage loss can be calculated from Eq. (10) and (9), respectively. Meanwhile, $n_{H_{2} \text { reacted }}$ is calculated for the reforming reactions, Eq. (1)-(2), and the fixed-fuel utilization.

$$
i=2 \mathrm{~F} \cdot n_{\mathrm{H}_{2} \text { reacted }}
$$

The activation polarization, $V_{\text {act }}$, occurs due to slow electron release or capture steps in the electrodeelectrolyte bilayer. This polarization could be evaluated by the Butler-Volmer equation, Eq. (11)-(13), [2527]. These equations were also applied in this work.

$$
\begin{gathered}
i=i_{0}\left[\exp \left(\alpha \frac{n_{e} F}{R T} V_{\text {act }}\right)-\exp \left(\left(-(1-\alpha) \frac{n_{e} F}{R T} V_{\text {act }}\right)\right]\right. \\
i_{0, H_{2}}=\vartheta_{\text {anode }}\left(\frac{p_{\mathrm{H}_{2}}}{p_{\text {ref }}}\right)\left(\frac{p_{\mathrm{H}_{2} \mathrm{O}}}{p_{\text {ref }}}\right) \exp \left(-\frac{\left.E_{\text {act,anode }}\right)}{R T}\right) \\
i_{0, O_{2}}=\vartheta_{\text {cathode }}\left(\frac{p_{\mathrm{O}_{2}}}{p_{\text {ref }}}\right)^{0.25} \exp \left(-\frac{E_{\text {act,cathode }}}{R T}\right)
\end{gathered}
$$

The concentration polarization, $V_{c o n}$, is caused by the limited diffusion of gaseous reactants and products species through the porous SOFC electrodes, as seen in Eq. (14). This polarization can be estimated by expressing the relative concentration difference of species participating in reaction sites and bulk SOFC flow. This reduction is controlled by Fick's law of diffusion inside the electrode pores. The final forms of anode and cathode overpotentials are given in the work of Chan, Khor [26], which include the effective of ordinary and Knudsen diffusion coefficients.

$$
V_{\text {con }}=\frac{R T}{2 F} \ln \left(\frac{p_{\mathrm{H}_{2}}^{*} p_{\mathrm{H}_{2} \mathrm{O}}}{p_{\mathrm{H}_{2}} p_{\mathrm{H}_{2} \mathrm{O}}^{*}}\right)+\frac{R T}{2 F} \ln \left(\frac{p_{\mathrm{CO}}^{*} p_{\mathrm{CO}_{2}}}{p_{\mathrm{CO}} p_{\mathrm{CO}_{2}}^{*}}\right)+\frac{R T}{4 F} \ln \left(\frac{p_{\mathrm{O}_{2}}^{*}}{p_{\mathrm{O}_{2}}}\right)
$$

where * represent gas partial pressure at active site.

The actual SOFC voltage $\left(V_{S O F C}\right)$ could be determined from Eq. (15) Meanwhile the net power output, $P_{S O F C}$, will be calculated by using Eq. (16).

$$
\begin{gathered}
V_{S O F C}=E-V_{o b m}-V_{a c t}-V_{c o n} \\
P_{S O F C}=V_{S O F C} \times i
\end{gathered}
$$

Table 2. SOFC material properties [27].

\begin{tabular}{|c|c|c|}
\hline Cell components & Material & Specific resistivity $(\boldsymbol{\Omega}$ m) \\
\hline Electrolyte & YSZ & $2.94 \times 10^{-5} \exp (10350 / T)$ \\
\hline Anode & $\mathrm{Ni} / \mathrm{YSZ}$ & $2.98 \times 10^{-5} \exp (-1392 / T)$ \\
\hline Cathode & $\mathrm{LSM}-\mathrm{YSZ}$ & $8.114 \times 10^{-5} \exp (600 / T)$ \\
\hline Inter-cell connector & Doped $\mathrm{LaCrO}_{3}$ & 0.0003215 \\
\hline
\end{tabular}




\subsection{System Efficiency Calculations}

Since a gasifier and a SOFC were integrated into this study, there were several efficiency parameters which were interested in calculating. Firstly, the electrical efficiency was calculated as the ratio of net electrical output generated (from the integration of SOFC with gasifier) to the biomass energy content fed to the gasifier, Eq. (17).

$$
\eta_{\text {elec }}=\left[\frac{P_{S O F C}}{\dot{m}_{\text {biomass }} \times L H V_{\text {biomass }}}\right]
$$

The thermal efficiency was considered as the ratio of net useful heat generated to biomass input, Eq. (18), while the overall efficiency was the sum of the net output of electrical and thermal energy to the input biomass feed, Eq. (18).

$$
\begin{gathered}
\eta_{\text {tbermal }}=\left[\frac{Q_{\text {use }}}{\dot{m}_{\text {biomass }} \times L H V_{\text {biomass }}}\right] \\
\eta_{\text {oevall }}=\left[\frac{Q_{\text {use }}+P_{S O F C}}{\dot{m}_{\text {biomass }} \times L H V_{\text {biomass }}}\right]
\end{gathered}
$$

\section{Results and Discussion}

The product composition and system efficiency of the gasification with different operating conditions (i.e. air-fed, steam-fed and mixed steam/air-fed) were firstly analyzed. It should be noted that the developed model was validated as the same method as our previous work [28]. Then, the SOFC system performance under nominal operational condition was studied as a reference scenario. As the major work, the electrical and thermal performance of SOFC system with different gasification operations were compared. Moreover, the operating conditions were varied at different equivalence ratio (ER) and steam to biomass ratio (SBR). It was noted that ER is the measuring of the amount of external oxygen supplied to the system, which obtained by dividing the actual oxygen to biomass molar ratio to the stoichiometric oxygen to biomass molar ratio. Meanwhile, SBR was defined as the mole steam fed per mole of biomass. The operating temperature was varied between $700-900{ }^{\circ} \mathrm{C}$ in order to achieve the intermediate temperature SOFC which is benefited for SOFC materials [32]. The use of too temperature (above $900{ }^{\circ} \mathrm{C}$ ) can damage the SOFC material. Finally, the optimum operation for SOFC coupling with biomass gasification would be suggested.

\subsection{Analysis of Gasification Reactions (with Air-, Steam- and Mixed Air/Steam)}

Before coupling with SOFC, the stand-alone gasification at different operating conditions (i.e. ER, SBR, operating temperature, and steam to air ratio) was analyzed. The compositions of the syngas after the gasifier were presented in our previous work [28]. The simulation results indicated that the main products from the biomass gasification are $\mathrm{H}_{2}, \mathrm{CO}, \mathrm{CO}_{2}$ with an insignificant amount of $\mathrm{CH}_{4}$ (less than $0.1 \%$ ). The highest hydrogen production from the steam gasification could be achieved when SBR was 4.0.

Not only amount of hydrogen production but the energy consumption for the system is also the important parameter. Therefore, the thermodynamic efficiency of these two processes was also investigated. At typical air gasification, the efficiency is dramatically decreased with increasing ER in the range of studied temperatures, as seen in Fig. 2(a), this might be caused by the reverse water gas shift reaction. Furthermore, the efficiency is slightly increased with increasing temperature (from $35 \%$ at $750^{\circ} \mathrm{C}$ to $42.5 \%$ at $900^{\circ} \mathrm{C}$ with ER of 0.2). This could be due to the reduction of SOFC overpotentials when the operating temperature is increased. In the case of steam gasification, the efficiency is initially increased with increasing SBR (from $26 \%$ at SBR of 0.5 to $32 \%$ at SBR of 2.5) due to impacts of the steam reforming reaction; then it is decreased at higher SBR, as seen in Fig. 2(b). Similar to the air gasification, the efficiency is increased (in the range of 5$10 \%$ ) with increasing temperature in all range of SBR. For the case of mixed air-steam gasification, the effects of ER and SBR on the thermodynamic efficiency are estimated at $900{ }^{\circ} \mathrm{C}$ as shown in Fig. 2(c). It 
can be seen that the efficiency is increased as ER and SBR are increased until reaching the optimum point. After that, the steam plays less impact on quantity of hydrogen production. Therefore, the efficiency would be reduced although ER and SBR are increased. The optimum condition for the mixed air-steam gasification is at the ER and SBR of 0.1 and 2.5, respectively. This condition could provide the efficiency up to $66.5 \%$. From this study, steam is more benefited for biomass gasification. When using steam as a gasified agent, the desired products are higher produced than using air.

\subsection{Outputs from SOFC System at Base Condition}

The electrical performance SOFC system with air gasification (using ER of 0.2) was firstly studied as the base condition. Theoretically, the cell voltage is influenced mainly operating condition and quantity of syngas. It can be estimated by considering the voltage losses i.e. ohmic, concentration and polarization losses. The voltage performance is decreased as the current density increased for SOFC operating temperature range of $700-900{ }^{\circ} \mathrm{C}$ as shown in Fig. 3. It could be seen that the slope of a line in this graph is significantly increased with decreasing temperature. This is the effect of exponential increasing of ohmic and activation resistances. These results are in good agreement with the results of the previous researchers $[22,29,30]$. In the meantime, the power output is initially increased with increasing the current density and then dropping down at high current density (Fig. 4).
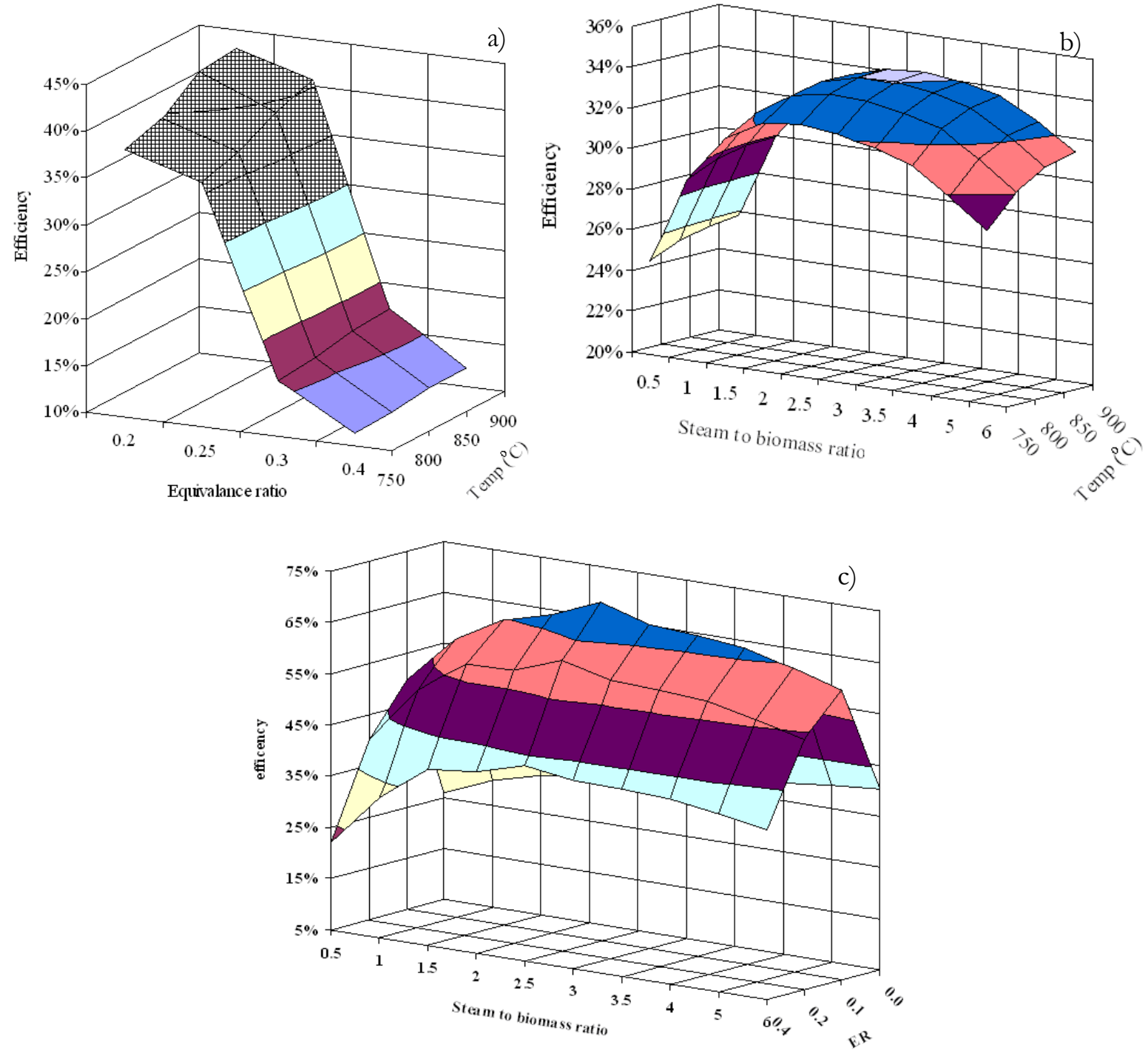

Fig. 2 Thermal efficiency of (a) air gasification, (b) steam gasification, and (c) mixed air/steam gasification at $900{ }^{\circ} \mathrm{C}$. 


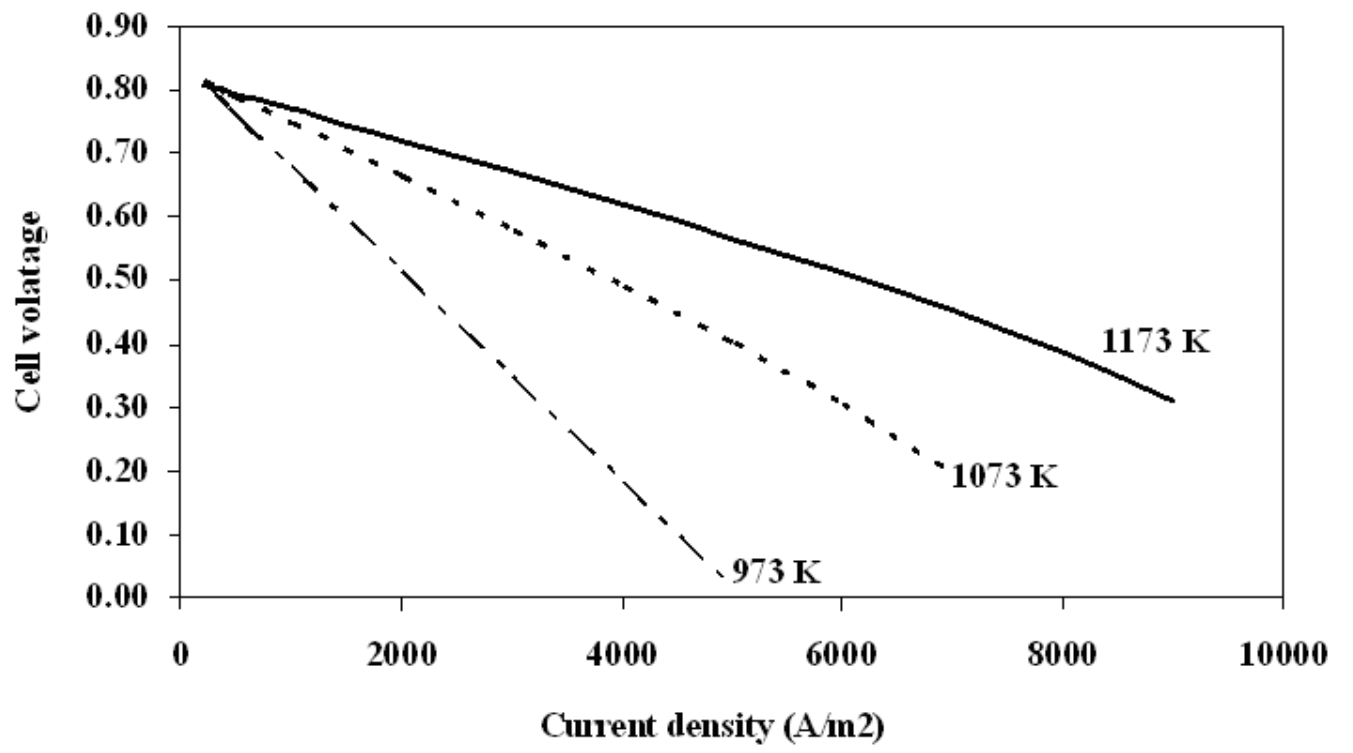

Fig. 3. Relation between cell voltage and current density at various temperatures.

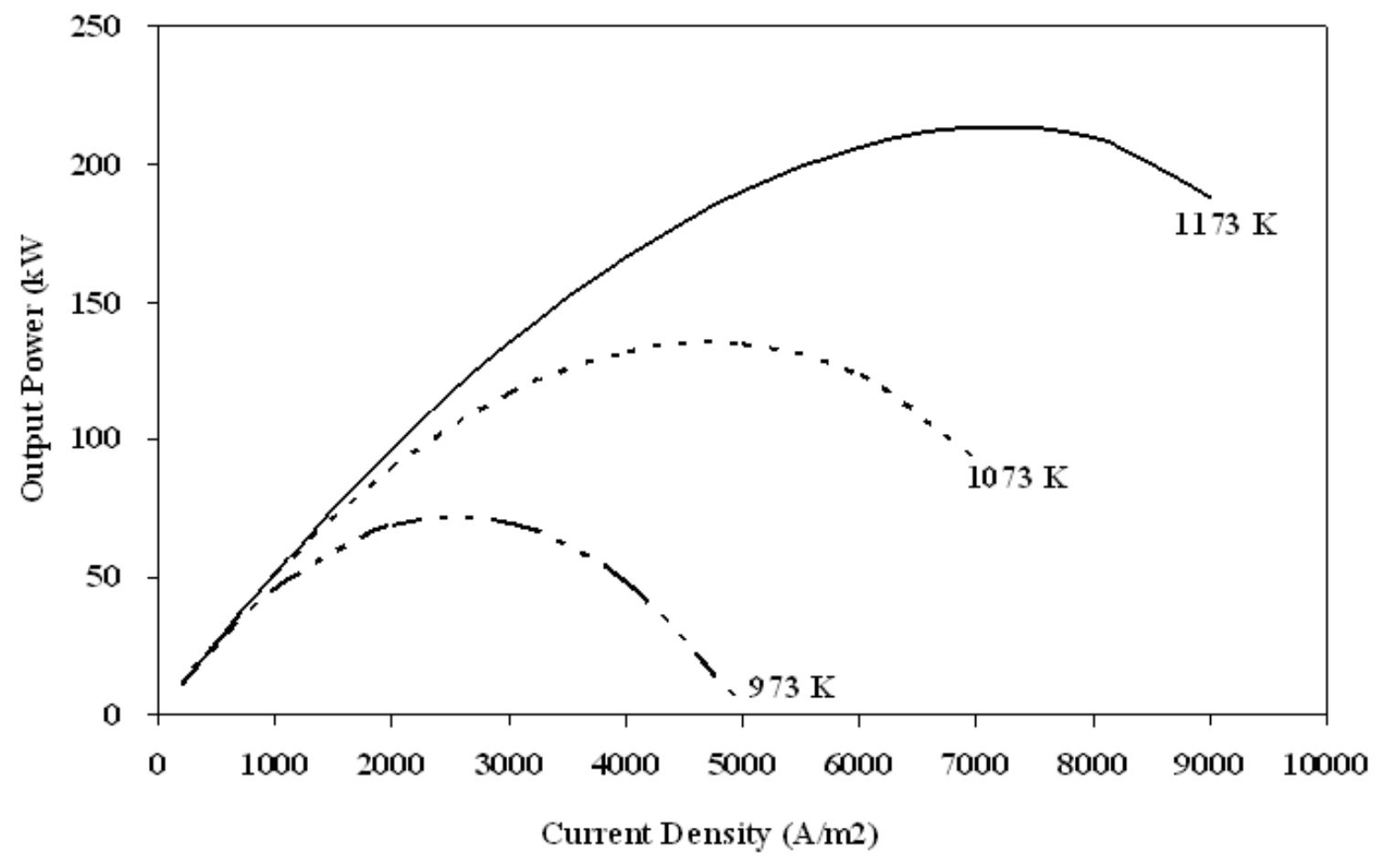

Fig. 4. Effect of current density on the power output from the SOFC system coupling with air gasification (at ER of 0.2 and $\mathrm{U}_{f}$ of 0.85 ).

\subsection{Effect of Operating Conditions on the Power Density}

The power density from the SOFC coupling with biomass gasification at different ER, SBR, operating temperature, and steam to air ratio were then studied. In the case of the SOFC coupling with steam gasification, the power density increased as the SBR and temperature increased (Fig. 5(a)), which could be due to the increasing of hydrogen from the stream gasification reaction and reducing of cell overpotentials. However, it can also be seen from the figure that the operating temperature showed only slight impact on the power density achievement. In the case of the SOFC coupling with air gasification, the power density at 
ER from 0.13 to 0.3 and gasification temperature from $700{ }^{\circ} \mathrm{C}$ to $900{ }^{\circ} \mathrm{C}$ is shown in Fig. 5(b). The power density decreased as the ER increased since production gas from gasifier is partially combusted. Conversely, the power density increased with increasing of gasification temperature, particularly at high ER value. This might be due to the reducing of resistant when the temperature increases. The maximum power density obtained from this operation is approximately $0.0577 \mathrm{~W} / \mathrm{cm}^{2}$ at $\mathrm{ER}$ of 0.13 , whereas the minimum value is $0.028 \mathrm{~W} / \mathrm{cm}^{2}$ at ER of 0.3 . In this investigation, increasing of the stream is benefited for the higher power density of all type of integrated system. As for the SOFC coupling with mixed air/steam gasification, the simulation is carried out by varying the ER from 0.13 to 0.3 , and SBR from 0.1 to 5.6 while keeping the operation temperature constant at $900{ }^{\circ} \mathrm{C}$ as shown in Fig. 5(c). It can be seen that the power density increased with increasing SBR but oppositely reduced by increasing ER. This is related to increase of syngas when SBR is increased as reported by Wongchanapai et.al [31]. Compared to the SOFC coupling with steam gasification, the power density estimated from the SOFC coupling with mixed air/steam gasification is relatively lower at the same operating temperature.

\subsection{Effect of Operating Conditions on the System Efficiency}

As the next step, the system efficiency from the SOFC coupling with these three type of gasification process was analysed at the operating temperature range of $700-900{ }^{\circ} \mathrm{C}$ by keeping the voltage constant at $0.7 \mathrm{~V}$ for all case studies. Figures $6(\mathrm{a})-(\mathrm{c})$ showed the trends of electrical, thermal and overall efficiency from the SOFC coupling with air gasification at various ER values in the range of temperature between 700-900 ${ }^{\circ} \mathrm{C}$. It can be seen from Fig. 6(a) that the electrical efficiency decreased with increasing the ER value particularly at low operating temperature and high ER value $(>0.2)$. The maximum electrical efficiency of $21.5 \%$ is predicted at ER of 0.17 and gasification temperature of $900{ }^{\circ} \mathrm{C}$. As the ER increased, the rapid reaction of biomass with oxygen occurred to form the higher amount of $\mathrm{CO}_{2}$, which reduced the syngas quantity and thereby resulted in lower electrical efficiency. According to the thermal efficiency prediction, similarly, it decreased with increasing of the ER values as shown in Fig. 6(b). Nevertheless, it can also be seen that as the gasification temperature increased from $700{ }^{\circ} \mathrm{C}$ to $900{ }^{\circ} \mathrm{C}$, the thermal efficiency gradually increased particularly at high ER values (from 24\% to 43\%) due to the releasing of high amount of heat and the further oxidation of unreacted CO from the burner, which significantly affect the net useful heat from the system. Lastly, for the overall efficiency, it is predicted to be in the range of $42-49 \%$ over the ranges of ER and gasification temperature studied, as seen in Fig. 6(c).

According to the SOFC system coupling with steam gasification, the electrical, thermal and overall efficiency are predicted in the SBR between 0.1 to 5.5 and gasification temperature between $750-900{ }^{\circ} \mathrm{C}$ as shown in Figs. 7(a)-(c). Clearly, the increasing of SBR and gasification temperature leaded to higher electrical efficiency achievement. At SBR value of 4.2, the efficiency is predicted to be $56 \%$. The high electrical efficiency achievement is due to the high production rate of $\mathrm{H}_{2}$ from the steam gasification particularly at high SBR and gasification temperature as shown in Fig. 8. This hydrogen-rich gas can be efficiently used by the electrochemical reaction to generate electricity. As for the thermal efficiency, it is initially increased with increasing SBR value and reached the maximum value of $55 \%$ at the SBR of 0.3 . Nevertheless, the thermal efficiency steadily dropped down from $55 \%$ to $25 \%$ at SBR of 4.2 . The decrease of thermal efficiency at high SBR value is related to the high input energy requirement to generate steam for the steam gasification reaction. A similar trend as thermal efficiency is also observed for the overall efficiency, in which the highest efficiency of $96 \%$ can be achieved, as shown in Fig. 7(c). Thus, it can be suggested that the suitable SBR for the SOFC coupling with steam gasification is 0.3 .

For comparison, the SOFC system coupling with mixed air-steam gasification is also analyzed. As shown in Fig. 9(a), the electrical efficiency increased with increasing SBR and/or decreasing ER. The highest efficiency of $43 \%$ can be achieved at the SBR of 5.6 and ER of 0.13 . As for the thermal efficiency, the high efficiency of $49 \%$ can be obtained at the low SBR and ER values (Fig. 9(b)). Lastly, the analysis of overall efficiency is presented in Fig. 9(c), in which the maximum efficiency of $80 \%$ can be reached. It can be seen that the efficiency of the SOFC system coupling with mixed air-steam gasification are greater than those of the SOFC system coupling with air gasification but relatively less than the SOFC system coupling with steam gasification. 

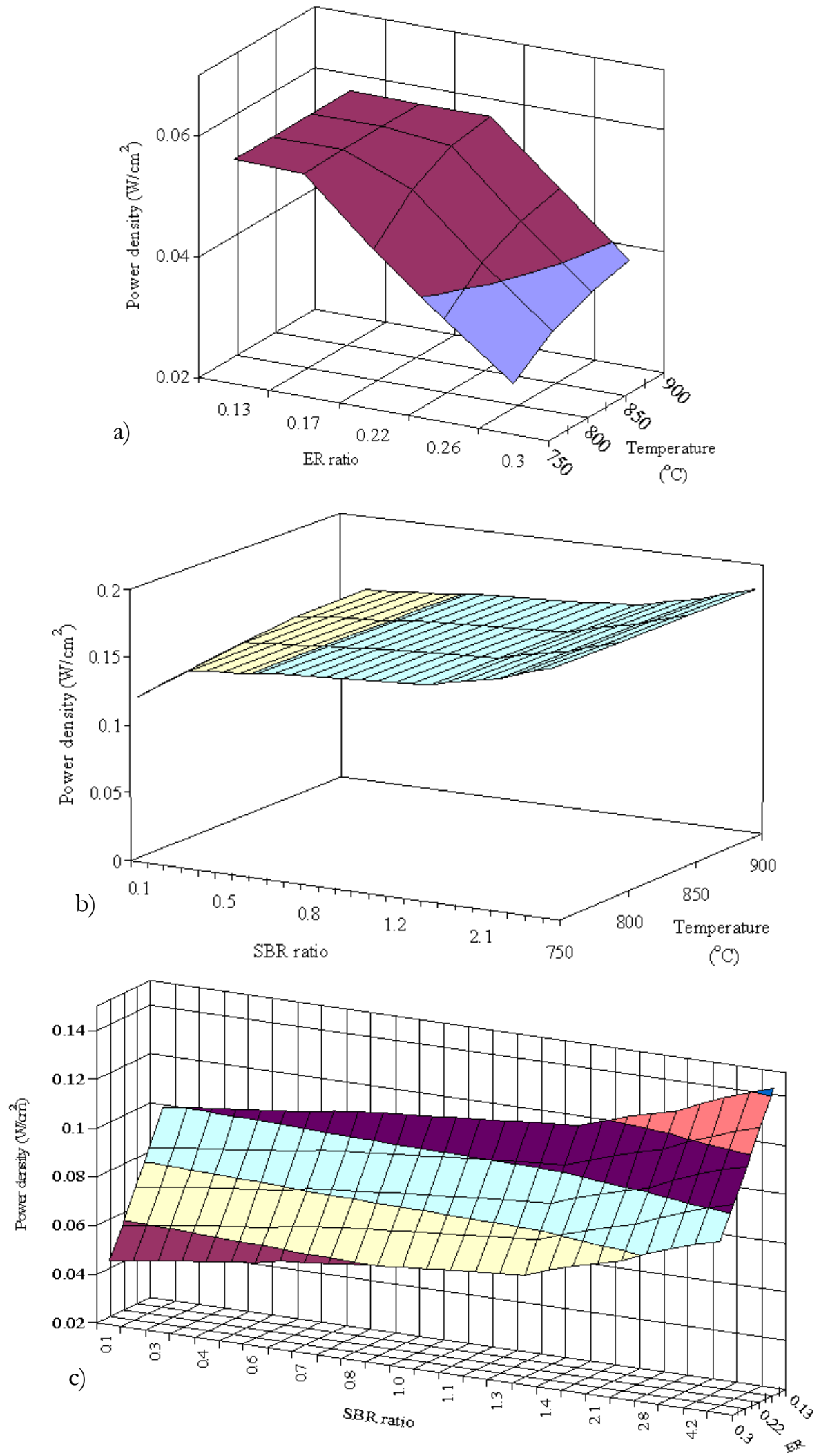

Fig. 5. The power density achievement from the SOFC Thermal efficiency of (a) air gasification, (b) steam gasification, and (c) mixed air/steam gasification at $900{ }^{\circ} \mathrm{C}$. 

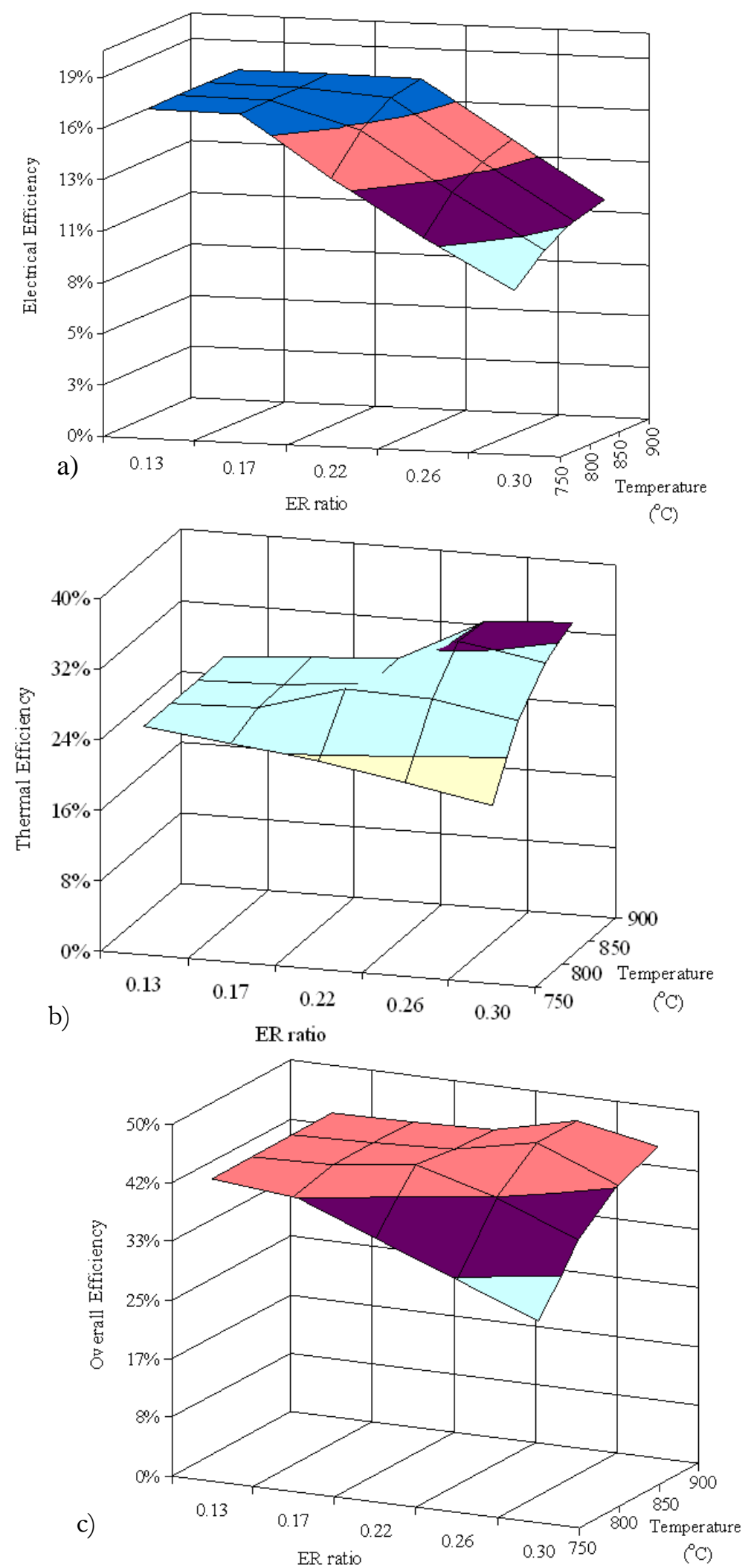

Fig. 6. (a) electrical efficiency, (b) thermal efficiency and (c) overall efficiency from the SOFC system coupling with air gasification. 
a)
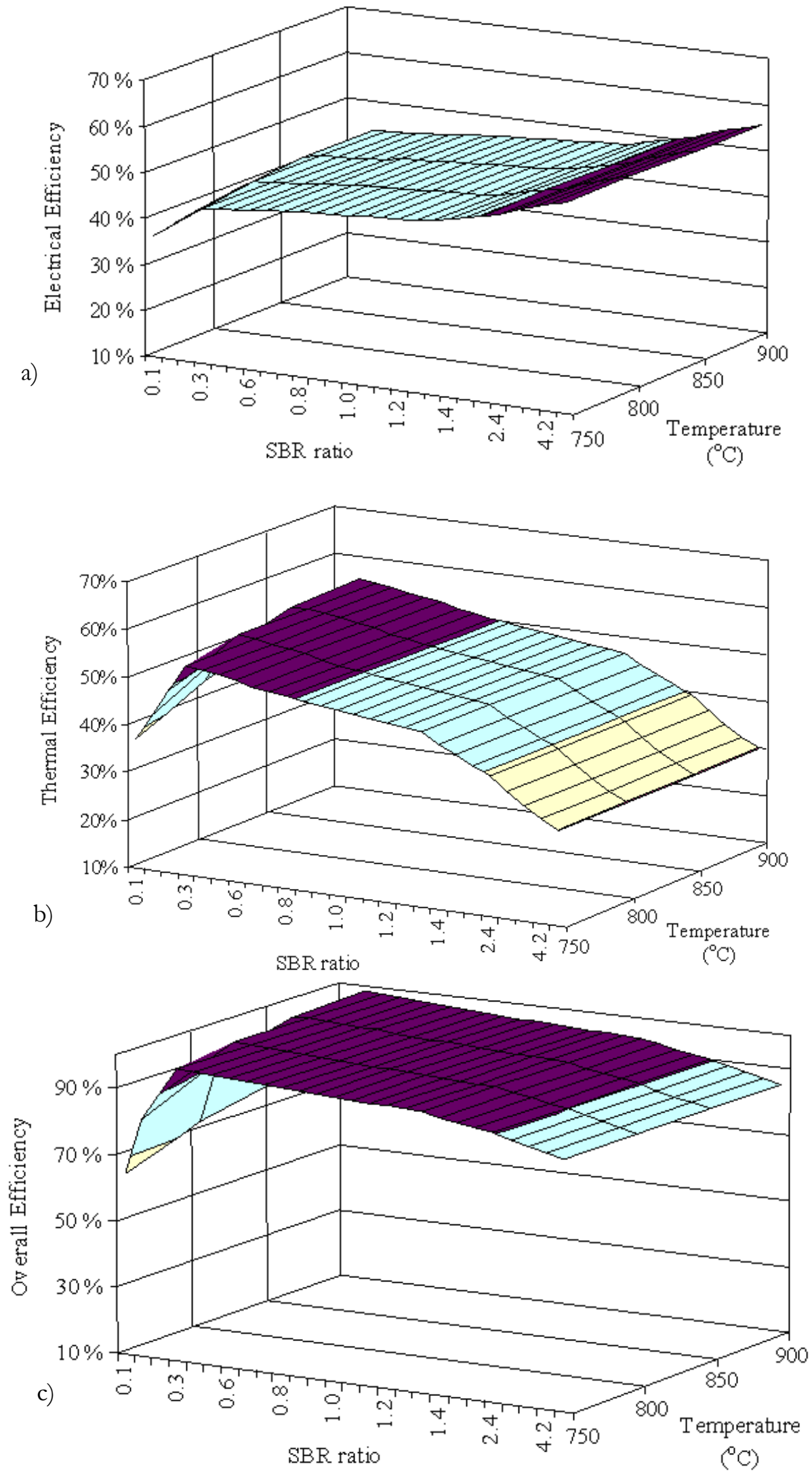

Fig. 7. (a) Electrical efficiency, (b) thermal efficiency and (c) overall efficiency from the SOFC system coupling with steam gasification. 


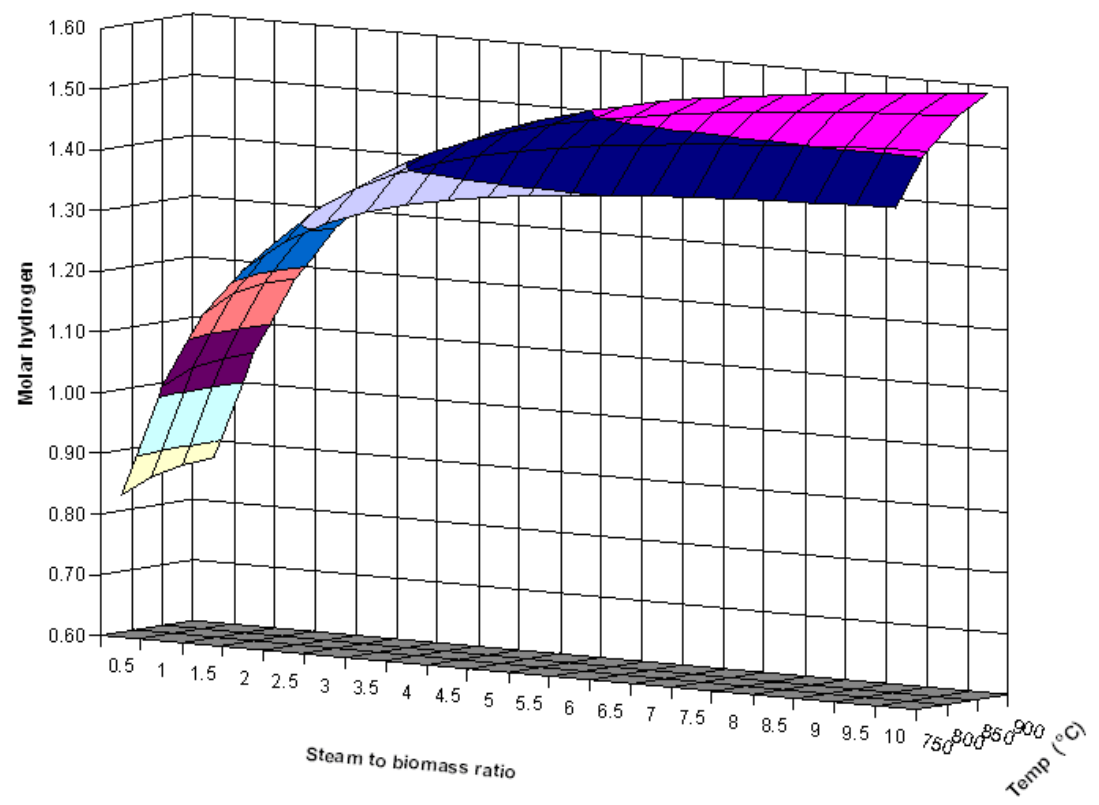

Fig. 8 the yield of $\mathrm{H}_{2}$ production from the steam gasification at various SBR (from 0.2 to 10).
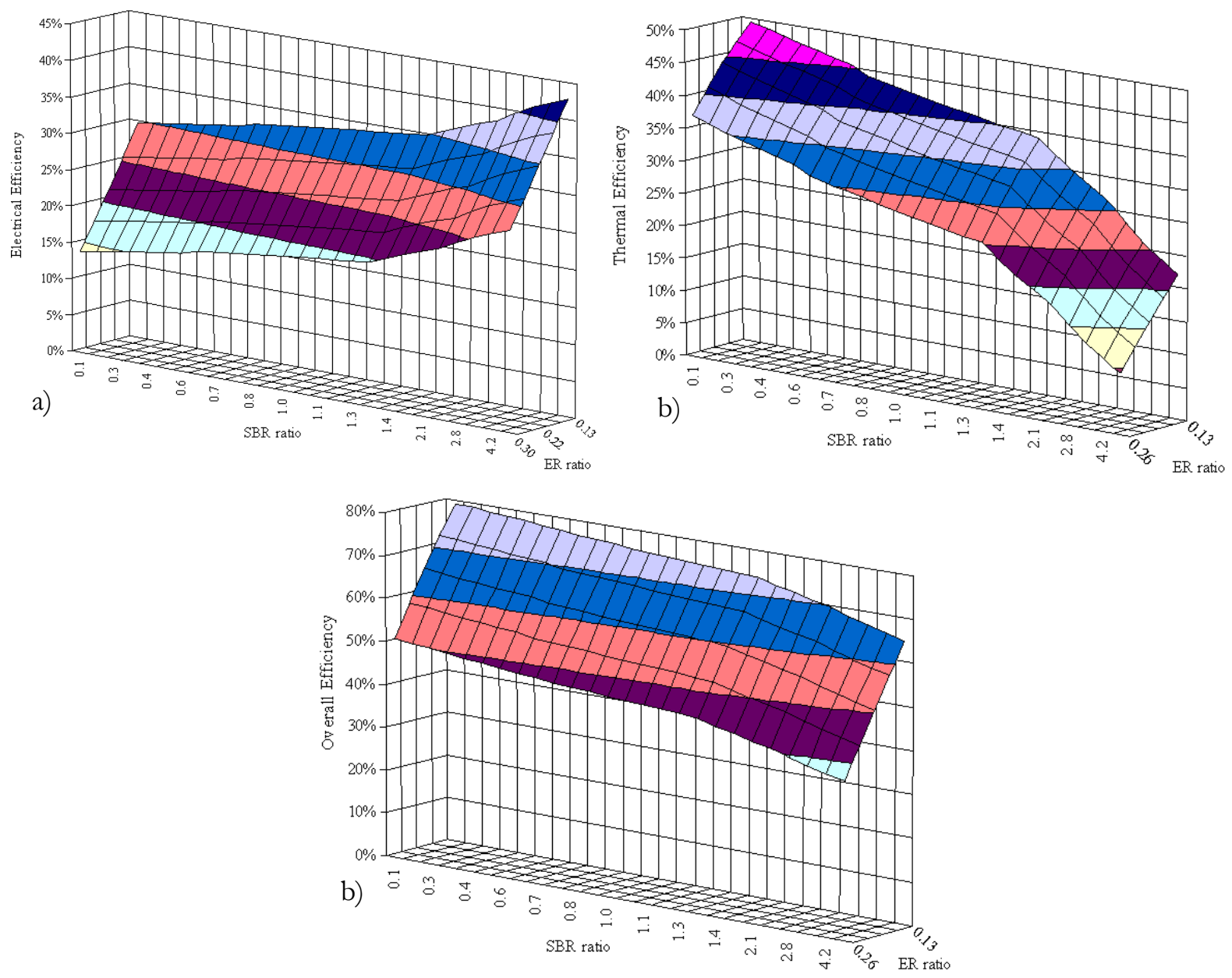

Fig. 9. (a) Electrical efficiency, (b) thermal efficiency and (c) overall efficiency from the SOFC system coupling with mixed air-steam gasification at $900^{\circ} \mathrm{C}$. 
In summary, according to our preliminary analysis, the mixed air-steam gasification produced hydrogen-rich gas with the highest efficiency compared to air and steam alone gasification. Nevertheless, when coupling the gasification with SOFC system, the steam gasification seems to be the greater option since a significant amount of heat is released from the electrochemical reaction of SOFC and it can be efficiently used for the endothermic steam gasification reaction to provide the autothermal operation.

\section{Conclusion}

System efficiency of integrated biomass gasification/solid oxide fuel cell system with various operations (i.e. air, steam and mixed air-steam gasification with different ER and SBR) are studied over Thailand rice husk. According to the SOFC coupling with air gasification, the maximum electrical efficiency of $21.5 \%$ is predicted at low ER (0.17) and the overall efficiency of $42-49 \%$ is obtained. As for the SOFC system coupling with mixed air-steam gasification, the highest electrical efficiency of $43 \%$ can be achieved at the SBR of 5.6 and ER of 0.13 ; and at the low SBR and ER, the thermal efficiency of $49 \%$ and the overall efficiency of $80 \%$ can be reached. For the SOFC system coupling with steam gasification, the electrical efficiency is predicted to be $56 \%$ at SBR value of 4.2 , whereas the thermal and overall efficiency increased with increasing SBR value and reached the maximum value of $55 \%$ and $96 \%$, respectively, at the SBR of 0.3 . It can be concluded from this study that, among all gasification/SOFC operations, the steam gasification is the suitable option for coupling with SOFC to general electricity from biomass since this system generated higher syngas than the air-, and mixed air/steam gasification. The higher amount of syngas eventually results in higher power generation.

\section{List of Nomenclatures}

\begin{tabular}{ll} 
AP & AspenPlus $\mathrm{TM}$ \\
$E$ & Potential, $\mathrm{V}$ \\
$E^{o}$ & Potential for standard temperature and pressure and pure reactants, $\mathrm{V}$ \\
$E_{\text {act }}$ & Activation energy, $\mathrm{kJ} / \mathrm{mol}$ \\
$\mathrm{ER}$ & Equivalence ratio \\
$F$ & Faraday's constant, $596,484 \mathrm{C} / \mathrm{mol}$ \\
$i$ & Current density, $\mathrm{A} / \mathrm{m}^{2}$ \\
$i_{0}$ & Exchange current density, $\mathrm{A} / \mathrm{m}^{2}$ \\
$L H V_{\text {biomass }}$ & Lower heating value of biomass, $\mathrm{kJ} / \mathrm{kg}$ \\
$\dot{m}_{\text {biomass }}$ & Mass flow of the biomass $(\mathrm{kg} / \mathrm{h})$ \\
$n_{j}$ & Amount of chemical substance, $j$, mole \\
$n_{e}$ & Number of electron \\
$p_{j}$ & Partial pressure of gas, $j$, from gasification reaction \\
$P_{\text {SOFC }}$ & Power density, $\mathrm{W} / \mathrm{m}^{2}$ \\
$Q_{\text {use }}$ & Net useful heat available after burning the spent gases from the SOFC stack, $\mathrm{kJ} / \mathrm{h}$ \\
$R$ & Universal gas constant; $8.414 \mathrm{~kJ} /$ mol K. \\
$R_{\text {ohm }}$ & Ohmic resistant, $\mathrm{k} \Omega \cdot \mathrm{m}^{2}$ \\
$\mathrm{SBR}$ & Stream to biomass ratio \\
$T$ & Temperature, $\mathrm{K}$ \\
$V_{\text {Act }}$ & Activation loss, $\mathrm{V}$ \\
$V_{\text {con }}$ & Concentration loss, $\mathrm{V}$ \\
$V_{\text {SOFC }}$ & Actual SOFC voltage, $\mathrm{V}$ \\
$V_{\text {ohm }}$ & Ohmic loss, $\mathrm{V}$ \\
\hline &
\end{tabular}




$\begin{array}{ll}\eta_{\text {elec }} & \text { Electrical Efficiency } \\ \eta_{\text {overall }} & \text { Overall Efficiency } \\ \eta_{\text {thermal }} & \text { Thermal Efficiency } \\ U_{f} & \text { Fuel utilization } \\ \vartheta & \text { Exchange current density } \\ \alpha & \text { Charge transfer coefficient }\end{array}$

\section{References}

[1] K. Laohalidanond, P. Chaiyawong, and S. Kerdsuwan, "Status of using biomass gasification for heat and power in Thailand," Energy Procedia, vol. 79, pp. 385-390, 2015.

[2] C. B. Field, J. E. Campbell, and D. B. Lobell, "Biomass energy: The scale of the potential resource," Trends Ecol Evol, vol. 23, no. 2, pp. 65-72, 2008.

[3] W. E. Council, "World Energy Resources: 2013 Survey," WEC, London, 2013.

[4] O. Edenhofer, R. Pichs-Madruga, Y. Sokona, K. Seyboth, S. Kadner, T. Zwickel, and P. Matschoss, "Renewable energy sources and climate change mitigation: Special report of the intergovernmental panel on climate change," Cambridge University Press, 2011.

[5] H. Balat and E. Kirtay, "Hydrogen from biomass-Present scenario and future prospects," Int. J. Hydrogen Ener, vol. 35, no. 14, pp. 7416-7426, 2010.

[6] N. Ni, D. Y. Leung, M. K. Leung, and K. Sumathy, "An overview of hydrogen production from biomass," Fuel Process Technol., vol. 87, no. 5, pp. 461-472, 2006.

[7] J. Schmidt, S. Leduc, E. Dotzauer, G. Kindermann, and E. Schmid, "Potential of biomass-fired combined heat and power plants considering the spatial distribution of biomass supply and heat demand,"Int. J. Energ. Res., vol. 34, no.11, pp. 970-985, 2010.

[8] F. P. Nagel, T. J. Schildhauer, and S. M. A. Biollaz, "Biomass-integrated gasification fuel cell systems-Part 1: Definition of systems and technical analysis," Int. J. Hydrogen Ener., vol. 34, no. 16, pp. 6809-6825, 2009.

[9] L. Wang, C. L. Weller, D. D. Jones, and M. A. Hanna, "Contemporary issues in thermal gasification of biomass and its application to electricity and fuel production," Biomass Bioenerg., vol. 32, no. 7, pp. 573$581,2008$.

[10] Y. Shi and N. Cai, "A general mechanistic model of solid oxide fuel cells," Tsinghua Sci. Technol., vol. 11, no. 6, pp. 701-711, 2006.

[11] A. B. Stambouli and E. Traversa, "Solid oxide fuel cells (SOFCs): A review of an environmentally clean and efficient source of energy," Renew. Sust. Energ. Rev., vol. 6, no. 5, pp. 433-455, 2002.

[12] A. O. Omosun, A. Bauen, N. P. Brandon, C. S. Adjiman, and D. Hart, "Modelling system efficiencies and costs of two biomass-fuelled SOFC systems," J. Power Sources, vol. 131, no. 1-2, pp. 96-106, 2004.

[13] K. D. Panopoulos, L. E Fryda, J. Karl, S. Poulou, and E. Kakaras, "High temperature solid oxide fuel cell integrated with novel allothermal biomass gasification: Part I: Modelling and feasibility study," $J$. Power Sources, vol. 159, no.1, pp. 570-585, 2006.

[14] P. Nehter, "A high fuel utilizing solid oxide fuel cell cycle with regard to the formation of nickel oxide and power density," J. Power Sources, vol. 164, no. 1, pp. 252-259, 2007.

[15] W. Doherty, A. Reynolds, and D. Kennedy, "Computer simulation of a biomass gasification-solid oxide fuel cell power system using Aspen Plus,” Energy, vol. 35, no. 12, pp. 4545-4555, 2010.

[16] C. Stiller, O. Mathisen, S. Seljebo, O. Bolland, H. Karoliussen, and B. Thorud, "Simulation-based comparison of combined SOFC/GT cycles with flat-plate and tubular fuel cell models," in Proceedings of the Fuel Cell Seminar, Miami, FL, 2003.

[17] L. Devi, K. J. Ptasinski, F. J. Janssen, S. V. van Paasen, P. C. Bergman, and J. H. Kiel, "Catalytic decomposition of biomass tars: use of dolomite and untreated olivine," Renew. Energ., vol. 30, no. 4, pp. 565-587, 2005.

[18] G. Schuster, G. Löffler, K. Weigl, and H. Hofbauer, "Biomass steam gasification-An extensive parametric modeling study," Bioresource Technol., vol. 77, no. 1, pp. 71-79, 2001. 
[19] T. Chungsangunsit, S. H. Gheewala, and S. Patumsawad, "Environmental assessment of electricity production from rice husk: A case study in Thailand," International Energy Journal, vol. 6, no. 1, pp. 347356, 2005.

[20] C. Pfeifer, R. Rauch, and H. Hofbauer, "In-bed catalytic tar reduction in a dual fluidized bed biomass steam gasifier," Ind. Eng. Chem. Res., vol. 43, no. 7, pp. 1634-1640, 2004.

[21] W. Zhang, E. Croiset, P. L. Douglas, M. W. Fowler, and E. Entchev, "Simulation of a tubular solid oxide fuel cell stack using AspenPlusTM unit operation models," Energ. Convers. Manage., vol. 46, no. 2, pp. 181-196, 2005.

[22] E. Fontell, T. Kivisaari, N. Christiansen, J. B. Hansen, and J. Pålsson, "Conceptual study of a 25 kW planar SOFC system for CHP application,” J. Power Sources, vol. 131, no. 1-2, pp. 49-56. 2004.

[23] P. Costamagna, L. Magistri, and A. F. Massardo, "Design and part-load performance of a hybrid system based on a solid oxide fuel cell reactor and a micro gas turbine," J. of Power Sources, vol. 96, no. 2, pp. 352-368, 2001.

[24] S. Campanari, "Full load and part-load performance prediction for integrated SOFC and microturbine systems," J. Eng. Gas Turb. Power, vol. 122, no. 2, pp. 239-246, 2000.

[25] J. Larminie and A. Dicks, Fuel Cell Systems Explained. Wiley, 2000.

[26] S. H. Chan, K. A. Khor, and Z. T. Xia, "A complete polarization model of a solid oxide fuel cell and its sensitivity to the change of cell component thickness," J. Power Sources, vol. 93, no. 1-2, pp. 130-140, 2001.

[27] D. A. Noren and M. A. Hoffman, "Clarifying the Butler-Volmer equation and related approximations for calculating activation losses in solid oxide fuel cell models," J. Power Sources, vol. 152, pp. 175-181, 2005.

[28] R. Kempegowda, S. Assabumrungrat, and N. Laosiripojana, "Thermodynamic analysis for gasification of Thailand rice husk with air, steam, and mixed air/steam for hydrogen-rich gas production," Int $J$ Chem React Eng, vol. 8, no. 1, 2010.

[29] W. Jamsak, S. Assabumrungrat, P.L. Douglas, E. Croiset, N. Laosiripojana, R. Suwanwarangkul, and S. Charojrochkul, "Thermodynamic assessment of solid oxide fuel cell system integrated with bioethanol purification unit," J. Power Sources, vol. 174, no. 1, pp. 191-198, 2007.

[30] M. Sucipta, S. Kimijima, and K. Suzuki, "Performance analysis of the SOFC-MGT hybrid system with gasified biomass fuel," J. Power Sources, vol. 174, no.1, pp. 124-135, 2007.

[31] S. Wongchanapai, "Development of direct internal reforming solid oxide fuel cell model and its applications for biomass power generation," Ph.D. thesis, Kyoto University, 2013.

[32] P. Dokmaingam, J. T. S. Irvine, S. Assabumrungrat, S. Charojrochkul, and N. Laosiripojana, "Modeling of IT-SOFC with indirect internal reforming operation fueled by methane: Effect of oxygen adding as autothermal reforming," Int. J. Hydrogen Ener., vol. 35, pp. 13271-13279, 2010. 